\title{
Molecular epidemiological study of Vibrio cholerae isolates from infected patients in Teheran, Iran
}

\author{
MOHAMMED R. POURSHAFIE, FRANCINE GRIMONT*, MAHNEZ SAIFI and \\ PATRICK A. D. GRIMONT* \\ Department of Bacteriology, Pasteur Institute of Iran, Teheran, Iran and*Institut Pasteur, Unite des \\ Enterobacteries, Unite INSERM 389, 75724 Paris Cedex 15, France
}

\begin{abstract}
A total of 110 clinical isolates of Vibrio cholerae 01 biotype El Tor serotype Ogawa isolated in a recent outbreak from different districts of Teheran, Iran, was subjected to 99 carbon source utilisation tests, ribotyping and toxinogenotyping. PCR showed that the genes encoding cholera toxin $(\operatorname{ctx} A)$, toxin co-regulated pilus (tcp), accessory cholera enterotoxin (ace) and zonula occludens toxin (zot) were present in $100 \%, 100 \%, 97.3 \%$ and $99.1 \%$ of the isolates, respectively. Restriction fragment length polymorphism (RFLP) study of the $B g l$ I-digested DNA probed with five oligonucleotides targeting the conserved regions of $16 \mathrm{~S}$ and $23 \mathrm{~S}$ rRNA genes revealed a similar ribotype pattern for 109 isolates. All but one isolate showed ribotype pattern B21a, containing seven bands with molecular sizes ranging from 11 to $3.9 \mathrm{~kb}$. The toxin gene restriction pattern (toxinogenotype) showed that the isolates carried either three or two copies of the toxin genes (ace, zot, ctx) which were recognised as TB41a and TB69 patterns, respectively. Overall, the ribotyping data showed that, despite biochemical differences in 12 of the 99 carbon sources, most of the isolates studied belonged to a single clone.
\end{abstract}

\section{Introduction}

Cholera is a severe diarrhoeal disease caused by certain serotypes of Vibrio cholerae which can lead rapidly to dehydration and death. Seven widespread pandemics of cholera have been recorded [1] and recently there have been increased reports of cholera outbreaks around the world. The seventh pandemic started with $V$. cholerae serotype O1 of El Tor biotype in 1961, which then disseminated throughout Asian countries and then to Europe [2]. In 1991, the pandemic was reported in South American countries and it was the first report of cholera in that region in this century [3]. The appearance of the new $V$. cholerae 0139 strain in 1992 in India [4] has also been observed in other countries and is believed to be the source of a new cholera pandemic [1], the eighth pandemic.

The epidemiological surveillance of cholera was limited in the past by insensitive laboratory typing systems [5]. However, previous work in this laboratory has resulted in the development of ribotyping based

Received 1 Nov. 1999; revised version accepted 3 April 2000.

Corresponding author: Dr F. Grimont (e-mail: fgrimont@pasteur.fr). upon restriction fragment length polymorphism (RFLP) of the $16 \mathrm{~S}+23 \mathrm{~S}$ rRNA genes [6-8], a highly conserved region of the bacterial genome. The ribotyping technique is now widely accepted as a powerful epidemiological tool [9-13] which has been applied extensively for the molecular characterisation of several bacterial species isolated in outbreaks.

This study was designed to investigate the biochemical and molecular characteristics of $V$. cholerae isolates from an outbreak in different districts of Teheran, Iran, in the summer of 1998. This is the first molecular epidemiological report from that part of the Middle East to characterise a large number of $V$. cholerae isolates.

\section{Materials and methods}

Specimen collection

A total of 110 stool samples was collected from patients suspected of having cholera in the summer of 1998 in Teheran, Iran. The samples were collected with sterile swabs which were then placed in Cary-Blair transport medium [14]. Alkaline peptone water was used for the enrichment of $V$. cholerae and the bacteria were then isolated on thiosulphate-citrate-bile-salt- 
sucrose (TCBS) agar medium (Sanofi Diagnostic Pasteur, Marnes-La Coquette, France) [14].

\section{Identification}

Biochemical identification and serotyping were done by standard procedures [15]. The bacterial carbon source utilisation profile was determined with Biotype-100 strips (bioMérieux, La Balme Les Grottes, France). The strips containing the carbon sources were inoculated with the bacterial suspensions according to the manufacturer's instructions and then the growth was read at 2 and 4 days after inoculation. The results were entered in the Recognizer ${ }^{\circledR}$ identification software program (Taxolab, Institut Pasteur, Paris, France). Serotyping was done with sera purchased from Eurobio (Les Ulis, France).

\section{Antibiotic susceptibility patterns}

Antibiotic susceptibility patterns were tested by the standard disk technique [16]. The following antibiotic disks were used: ampicillin $(10 \mu \mathrm{g})$, chloramphenicol (30 $\mu \mathrm{g})$, co-trimoxazole, ciprofloxacin $(5 \mu \mathrm{g})$, gentamicin $(10 \mu \mathrm{g})$, tetracycline $(30 \mu \mathrm{g})$, erythromycin $(15 \mu \mathrm{g})$, oxytetracycline $(30 \mu \mathrm{g})$ and polymyxin (300 IU). All antibiotic disks were purchased from Difco Laboratories (Detroit, MI, USA).

\section{DNA extraction}

DNA was extracted as described previously [17]. Briefly, a single colony was removed from bacterial growth on TCBS agar and inoculated into tryptocasein soy broth (TCS; Sanofi Diagnostic Pasteur). The cultures were then centrifuged and the pellets were lysed with lysing buffer solution containing $0.1 \mathrm{M}$ $\mathrm{NaCl}, 50 \mathrm{M}$ EDTA and $0.1 \mathrm{M}$ Tris- $\mathrm{HCl}$ ( $\mathrm{pH}$ 8.0) supplemented with sodium dodecyl sulphate (SDS) $0.5 \% \mathrm{w} / \mathrm{v}$ and proteinase $\mathrm{K} 0.5 \mathrm{mg} / \mathrm{ml}$. DNA was then extracted with the AutoGen 540 system (AutoGen Instruments, Beverly, MA, USA).

\section{Gene detection by PCR}

PCR was performed in a reaction mixture containing sterile water $35 \mu \mathrm{l}, 10 \times \operatorname{Taq}$ polymerase buffer $5 \mu \mathrm{l}$,
$200 \mu \mathrm{M}$ deoxynucleotide phosphate (dNTP), Taq DNA polymerase (Amersham Pharmacia Biotech, Uppsala, Sweden) 2.5 units, DNA template $1 \mu \mathrm{l}$ and $50 \mathrm{pmol}$ of each primer. The primers were cholera toxin gene $(\operatorname{ctx} \mathrm{A})$, accessory cholera enterotoxin gene (ace), zonula occludens toxin gene (zot) and toxin-coregulated pilus gene (tcpA) (Table 1) $[10,18-20]$ and were synthesised and purified by Genset (Paris, France). The cycling conditions were as follows: preincubation at $94^{\circ} \mathrm{C}$ for $5 \mathrm{~min}, 35$ cycles of $1 \mathrm{~min}$ at $94^{\circ} \mathrm{C}$ for denaturation, $1 \mathrm{~min}$ at $64^{\circ} \mathrm{C}$ for annealing, $2 \mathrm{~min}$ at $72^{\circ} \mathrm{C}$ for elongation and incubation at $72^{\circ} \mathrm{C}$ for $3 \mathrm{~min}$ for final elongation. The amplicons were electrophoresed through agarose $0.8 \%$ gel (Appligene, Illkirch, France) and then stained with ethidium bromide. A negative control (reaction mixture without template) and a toxin positive control ( $V$. cholerae $\mathrm{O} 1$ strain O395) were included in each run [10].

\section{Ribotyping}

The DNA extracted from the $V$. cholerae isolates was cleaved by restriction endonuclease $B g l \mathrm{I}$ (Life Technologies, Cergy Pontoise, France) $20 \mathrm{U} / \mu \mathrm{l}$ at $37^{\circ} \mathrm{C}$ for at least $4 \mathrm{~h}$. The fragments were then separated by electrophoresis in an agarose $0.8 \%$ gel (Appligene) in Tris borate buffer $(89 \mathrm{mM}$ Tris, $89 \mathrm{mM}$ borate, $2 \mathrm{mM}$ EDTA, $\mathrm{pH} 8.3$ ) for $16 \mathrm{~h}$ at $1.5 \mathrm{~V} / \mathrm{cm}$. The DNA fragments were transferred to nylon membranes (Hybond N+, USB Life Science) by the alkali blotting procedure with a vacuum blotter (Amersham Pharmacia Biotech). Hybridisation was performed with a probe labelled with digoxigenin-11-dUTP (DIG) [21]. The membranes were then visualised by addition of alkaline phosphatase-conjugated anti-digoxigenin antibody (anti-DIG-AP; Boehringer Mannheim GmbH, Germany) and 5-bromo-4-chloro-3-indolyl phosphate substrate and nitroblue tetrazolium (Research Organics, Cleveland, OH, USA) [18]. Digitisation and interpretation of patterns were done with programs in the Taxotron package (Taxolab). The membranes were first scanned and the images were then searched for bands by RestrictoScan. The fragment sizes were interpolated from migration data by RestrictoTyper [11, 22, 23]. Citrobacter koseri strain CIP 105177 (Collection de l'Institut Pasteur) DNA was cleaved by Mlu I (Amersham Pharmacia Biotech) restriction endonuclease and

Table 1. Oligonucleotides used for PCR amplification of the toxin genes

\begin{tabular}{lllc}
\hline Gene & Oligonucleotide & Sequence & Reference \\
\hline ctxA & ctx1 & ctx2 & 5'-CGG GCA GAT TCT AGA CCT CCT G-3' \\
& & 5'-CGA TGA TCT TGG AGC ATT CCC AC-3' & 18 \\
ace & ace1 & & \\
& ace2 & 5'-TAA GGA TGT GCT TAT GAT GGA CAC CC-3' & 19 \\
zot & zot1 & 5'-CGT GAT GAA TAA AGA TAC TCA TAG 3' & \\
& zot2 & 5'-TGG CTT CGT CTG CTG CCG GCG ATT-3' & 10 \\
tcpA & tcp525 & 5'-CAC TTC TAC CCA CAG CGC TTG CGC-3' & \\
& tcp568 & 5'-AAA GAG CTC GAT CTC CAC TCC GGA AAT A-3' & 20 \\
\hline
\end{tabular}


the fragments were used as molecular size standards. For some experiments, DNA extracted from $V$. cholerae isolates was cleaved by HindIII and SalI restriction endonuclease (Life Technologies).

\section{Toxinogenotyping}

Toxinogenotyping was performed on the ribotype membranes as described previously [11] with some modifications. The membranes were hybridised with the probe constructed by amplification of the virulence cassette containing ace, zot, ctx $A$ and $c t x B$ genes. The primers were chosen at the $5^{\prime}$-end of the ace gene and the $3^{\prime}$-end of the $\operatorname{ctx} B$ gene (Table 2) $[19,24]$. The probe was labelled with DIG with the DIG-DNA labelling kit (Boehringer Mannheim) at $37^{\circ} \mathrm{C}$ for $1 \mathrm{~h}$. The reaction was then stopped and the labelled DNA was precipitated by addition of $4 \mathrm{M}$ lithium chloride and absolute ethanol. Hybridisation was performed by incubating the target DNA with the DIG-labelled probe at $53^{\circ} \mathrm{C}$ for $16 \mathrm{~h}$. After post-hybridisation washes, the membranes were blocked and anti-DIG-AP antibody was added as described in the previous section. The membranes were incubated with CSPD substrate (Boehringer Mannheim) and then exposed to Biomax films (Kodak, Rochester, NY, USA).

\section{Results}

\section{Biochemical analysis}

All the isolates studied showed the serological and classical biochemical reations typical of $V$. cholerae and were identified as $V$. cholerae $\mathrm{O} 1$ biotype El Tor serotype Ogawa. For further biochemical analysis of the isolates, Biotype-100 strips, including 99 different carbon sources, were used. All the isolates showed the same carbon source profile for 87 carbon sources available in the Biotype-100 strips with the exception of 1-O-methyl- $\beta$-galactopyranoside, $\mathrm{D}(+)$ malate, $\mathrm{L}(+)$ arabinose, aesculin, 4-aminobutyrate, 1-O-methyl- $\alpha$-Dglucopyranoside, L-alanine, 3-O-methyl-D-glucopyranose, propionate, palatinose, $\alpha$-L-rhamnose and Ltyrosine (Table 3). Among the variable test results, the most and least positive results for utilising a single carbon source were L-tyrosine (22\% positive) and $\alpha$-Lrhamnose ( $93 \%$ positive), respectively. Numerical taxonomy of the results obtained from Biotype-100 strips indicated that the maximum biochemical difference amongst the 110 isolates was c. $2 \%$ (data not shown).

\section{Antibiotic susceptibility patterns}

The antibiotic susceptibility patterns showed that all isolates were resistant to polymyxin $\mathrm{B}$, vibriostatic agent $\mathrm{O} / 129$, tetracycline, co-trimoxazole, and oxytetracycline. The isolates also showed intermediate resistance to chloramphenicol. On the other hand, all the isolates were susceptible to ciprofloxacin, erythromycin, gentamicin and doxytetracycline.

\section{Distribution of the amplified toxin genes}

The $V$. cholerae isolates were analysed for the presence of $c t x$, zot, ace and tcp genes by PCR with specific primers. Table 4 shows that most $V$. cholerae isolates had all four genes $(97.3 \%)$. Two $(1.8 \%)$ and one $(0.9 \%)$ isolates lacked the ace and the combined ace/zot genes, respectively. The $c t x A$ and $t c p A$ genes were present in all the isolates.

\section{Ribotyping and toxinogenotyping analysis}

Ribotyping showed seven fragments corresponding to molecular sizes of $c$. 12.0, 10.0, 6.7, 6.3, 6.0, 4.5 and $4.0 \mathrm{~kb}$ (Fig. 1, lane 2). Analysis of 109 isolates of $V$. cholerae indicated a similar pattern, which in this

Table 3. Variable results in metabolising 12 different carbon sources out of 99 carbon sources of Biotype-100 strips by $V$. cholerae isolates

\begin{tabular}{lc}
\hline Carbon source & $\begin{array}{c}\text { Bacteria utilising a } \\
\text { single carbon source (\%) }\end{array}$ \\
\hline$\alpha$-L-Rhamnose & 93 \\
Palatinose & 92 \\
1-O-Methyl- $\beta$-galactopyranoside & 85 \\
D(+)Malate & 84 \\
L(+)Arabinose & 77 \\
Aesculin & 68 \\
4-Aminobutyrate & 65 \\
1-O-Methyl- $\alpha$-D-glucopyranoside & 59 \\
L-Alanine & 48 \\
3-O-Methyl-D-glucopyranose & 34 \\
Propionate & 22 \\
L-Tyrosine & 22 \\
\hline
\end{tabular}

Table 4. Distribution of $c t x A$, ace, zot and tcpA genes in $110 \mathrm{~V}$. cholerae isolates

\begin{tabular}{lc}
\hline Toxin genes present & Number of isolates $(\%)$ \\
\hline $\operatorname{ctx} A, \operatorname{tcp} A$, zot, ace & $107(97.3)$ \\
$\operatorname{ctx} A, \operatorname{tcp} A$, zot & $2(1.8)$ \\
$\operatorname{ctx} A, \operatorname{tcp} A$ & $1(0.9)$ \\
\hline
\end{tabular}

Table 2. Primers used for the amplification of the virulence cassette in the toxinogenotyping method

\begin{tabular}{llc}
\hline Oligonucleotide & Sequence & Reference \\
\hline$a c e$ & 5'-TAA GGA TGT GCT TAT GAT GGA CAC CC-3' & 19 \\
$c t x B$ & 5'ATT GCG GCA ATC GCA TGA GGC GT-3' & 24 \\
\hline
\end{tabular}




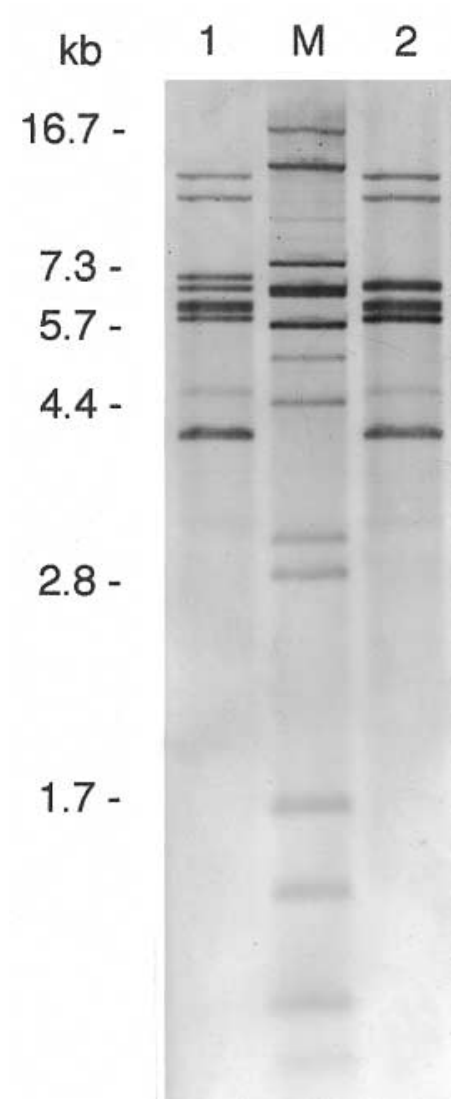

Fig. 1. Ribotype analysis of $V$. cholerae DNA digested with $B g l$ I restriction endonuclease. Numbers on the left indicate the molecular size of the bands of Citrobacter koseri strain DNA (CIP 105177) cleaved with Mlu I restriction endonuclease (mol. wt marker; M). Lane 1, the new ribotype pattern of a single isolate with an extra band of $7.1 \mathrm{~kb} ; 2$, ribotype pattern B21a, typical for 109 isolates of $V$. cholerae.

database was identified as ribotype B21a. However, one isolate had an extra fragment of $7.1 \mathrm{~kb}$ (Fig. 1, lane 1) which did not fit any known ribotype $[8,12]$. The study next examined the effectiveness of other restriction endonucleases in discriminating the isolates of $V$. cholerae by ribotyping. Fig. 2 shows the schematic representation of the isolates after digestion to HindIII and SalI restriction endonucleases. Digestion of the DNA extracts of the isolates with HindIII resulted in nine fragments with molecular sizes ranging from 8.8 to $1.3 \mathrm{~kb}$ for all the isolates studied. Utilisation of Sal I restriction endonuclease resulted in 10 fragments with molecular sizes ranging from 16.0 to $2.7 \mathrm{~kb}$. The ribotype pattern of $V$. cholerae isolate no. 1 was similar to other isolates following digestion by HindIII or SalI, suggesting that the latter two enzymes had less discriminatory power than $B g l \mathrm{I}$.

To examine how different the isolates were from one another with regard to the molecular size and the chromosomal location of the virulence cassette, RFLP of the $B g l$ I digested DNA was determined with a DIGlabelled virulence cassette probe (Table 2) with a molecular size of $c .3 .0 \mathrm{~kb}$. The data indicated that most of the isolates $(93 \%)$ had the same profile and carried three bands with molecular sizes of $c$. 12.0, 7.9 and $3.4 \mathrm{~kb}$ (Fig. 3, lane 2). The results were suggestive of toxinogenotype TB41a, as suggested by Koblavi [12]. On the other hand, some strains (7\%) showed only two bands with molecular sizes of $c .12$ and $3.4 \mathrm{~kb}$, thus lacking the 7.9-kb band (Fig. 3, lane 1). This pattern was identified as toxinogenotype TB69. No absolute correlation was found between ribotype and toxinogenotype systems. However, the data indicated that toxinogenotyping could subdivide ribotypes. The overall results indicated that a majority $(93 \%)$ of the isolates belonged to ribotype/toxinogenotype B21a/ TB41a and other isolates were B21a/TB69 (7\%). The single strain with no known ribotype showed toxinogenotype TB41a.

\section{Discussion}

Recently, there has been a new surge of reports of cholera around the world. In 1993, 78 countries

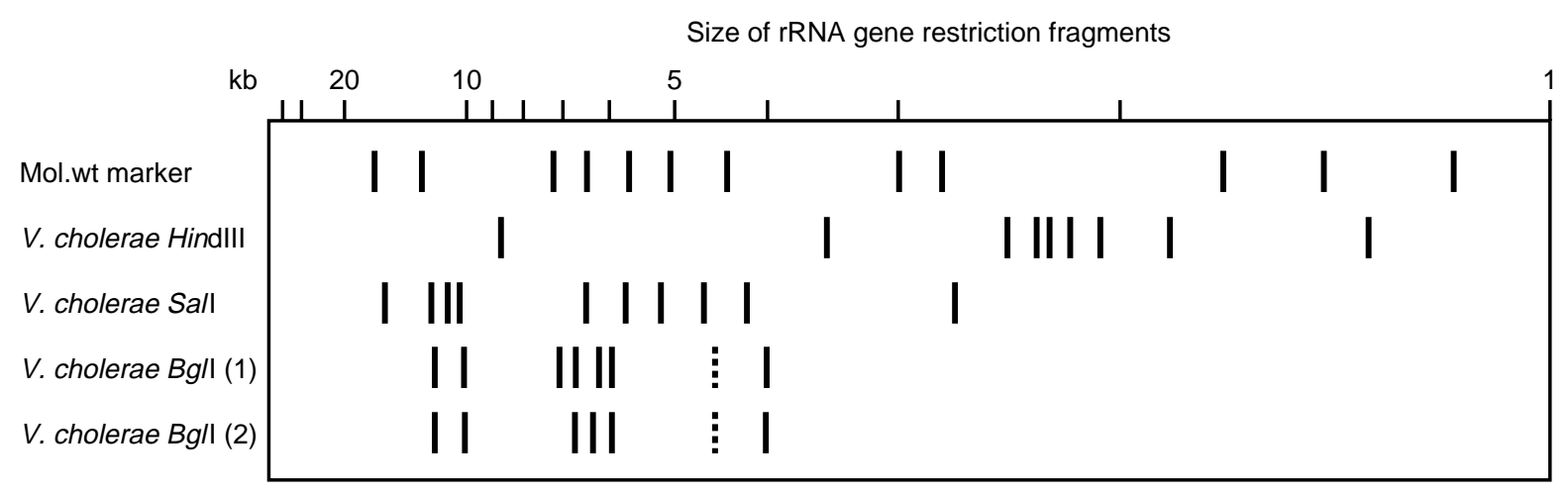

Fig. 2. Schematic representation of $V$. cholerae DNA digested by HindIII, SalI and BglI restriction endonucleases. Number 1 in parentheses indicates the only isolate of $V$. cholerae with a different ribotype pattern after digestion by BglI. Number 2 in parentheses indicates the ribotype pattern of 109 isolates of $V$. cholerae examined (B21a). The DNA restriction pattern for all 110 isolates of $V$. cholerae was identical when digested by HindIII or SalI restriction endonucleases. 


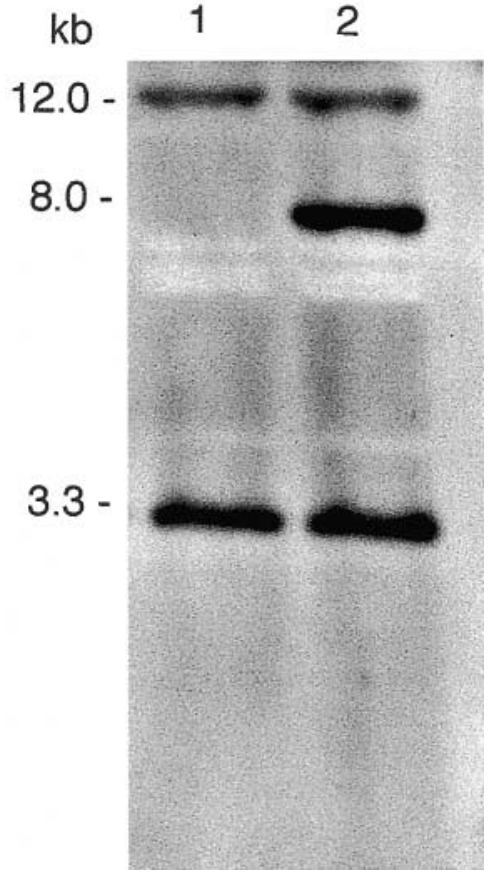

Fig. 3. Toxinogenotype pattern of $V$. cholerae O1. The same ribotype membranes were used for the toxinogenotyping. The bands represent the DNA fragments which hybridised with the virulence cassette and the numbers indicate the size of the $B g l \mathrm{I}$-cleaved DNA fragments. The sizes of the toxinogenotype bands were calculated by extrapolation of the ribotype bands (evident as clear bands). Lane 1, pattern TB69; 2, pattern TB41a.

reported cholera to the World Health Organization with more than 376000 people affected and 6700 deaths [25]. Of course, the numbers could be higher, as adequate surveillance may not exist in some of the developing countries. Several factors such as deterioration of the urban infrastructure in some countries, immigration and the emergence of the new strains of $V$. cholerae have fostered the re-appearance of pandemic cholera. In particular, the emergence of multiple antibiotic resistance in $V$. cholerae strains is a major concern. The results of the antibiotic susceptibility tests on the $V$. cholerae isolates studied here support previous reports that $\mathrm{O} / 129$ (2,4-diamino 6,7-diisopropylpteridine phosphate) is no longer a useful taxonomic tool for distinguishing Vibrio spp. [13,26] and that continuous monitoring of the antibiotic susceptibility of this species is needed.

The use of PCR for the detection of the cholera toxin (CT) and other toxin genes which are located on a 4.5$\mathrm{kb}$ region of the $V$. cholerae virulence cassette has been reported extensively. However, reports regarding the use of PCR have been variable with regard to the number of the positive strains carrying the genes in the virulence cassette. There are reports that $0-20 \%$ of isolates lacked all or at least one of the genes located in the virulence cassette [27-31]. In the present study, only $3.6 \%$ of the isolates lacked one or more of the toxin genes, which supports the suggestion by other investigators $[11,32,33]$ that deletion of the genes in the virulence cassette could occur. Furthermore, the results of toxinogenotyping indicated that some of the isolates lacked a single band of the virulence cassette, which may indicate a mutation within the $B g l$ I cutting sequence in some of the isolates.

RFLP of the rRNA genes has been applied extensively in the last several years for the epidemiological investigation of micro-organisms $[7,8,12,34-36]$. The technique has been shown to be one of the most discriminatory tools for epidemiological studies of $V$. cholerae [28,37]. Koblavi et al. [8] have subtyped 72 El Tor strains isolated from Asia, Africa and Pacific Islands into 13 different ribotypes. Ribotyping of a number of strains from various countries has revealed $\mathrm{B} 5 \mathrm{a}$ as the predominant ribotype pattern in the seventh pandemic $[8,38]$. There are also reports indicating that a single ribotype pattern can be unique to a specific region or responsible for a specific outbreak. For example, to date $\mathrm{B} 9 / \mathrm{B} 10$ ribotype patterns have been reported specifically in Australia [38], and V. cholerae strains isolated from Senegal and some of the strains from Guinea-Bissau were shown to have ribotype B27 [13]. The present study showed that the ribotype of the $V$. cholerae isolates, based on the BglI cleavage patterns of their rRNA genes, produced a single reproducible pattern corresponding to ribotype B21a of Koblavi's published scheme [12] for the isolates studied. Previously in this laboratory, pattern B21a has been identified in $V$. cholerae isolates from Turkey, Romania, Pakistan, Lebanon, Cambodia and Italy [12] which resembles the ribotype pattern of $6 a$ as suggested by Popovic et al. [38]. However, the data presented here represent the first extensive study of a large number of $V$. cholerae isolates, which may indicate that the $\mathrm{B} 21 \mathrm{a}$ ribotype with the toxinogenotype pattern of TB41a is the predominant strain of $V$. cholerae in a particular area of the Middle East. Thus, one strain B21a TB69, serotype Ogawa was found by Damian et al. [11] in 1991 in Constanta (Romania).

Furthermore in the present study, a single isolate of $V$. cholerae had a unique ribotype pattern that did not match any of the profiles presented in the standardised scheme [38] or in our database, which contains c. 50 different pattens of $V$. cholerae isolates collected from different continents [12]. The pattern of this unique strain may indicate that the strain has emerged as the result of mutation or represents a subdivision of the B21a ribotype which has been undetected previously.

Further analysis of sporadic cases of $V$. cholerae isolates in Iran has also confirmed B21a as the predominant pattern.

This research was supported by the Reseau International des Instituts Pasteur et Associes, Institute Pasteur, Paris, France and also, in part, by the Iran Ministry of Health, Department for Combating Contagious Diseases. Special thanks to Dr G. M. Giammanco and Mrs E. Ageron for their assistance. 


\section{References}

1. Kaper JB, Morris JG, Levine MM. Cholera. Clin Microbiol Rev 1995; 8: 48-86.

2. Kamal AM. The seventh pandemic of cholera. In: Barua D, Burrows W (eds) Cholera. Philadelphia, WB Saunders. 1974: $1-14$.

3. Levine MM. South America: the return of cholera. Lancet 1991; 338: 45-46.

4. Cholera Working Group. International Centre for Diarrhoeal Diseases Research, Bangladesh. Large epidemic of cholera-like disease in Bangladesh caused by Vibrio cholerae 0139 synonym Bengal. Lancet 1993; 342: 387-390.

5. Wachsmuth K, Olsvik O, Evins G, Popovic T. Molecular epidemiology of cholera. In: Wachsmuth K, Blake P, Olsvik O (eds) Vibrio cholerae and cholera. Washington, DC, American Society for Microbiology. 1994.

6. Grimont F, Grimont PAD. Ribosomal ribonucleic acid gene restriction patterns as potential taxonomic tools. Ann Inst Pasteur Microbiol 1986; 137B: 165-175.

7. Grimont F, Lefevre M, Ageron E, Grimont PAD. rRNA gene restriction patterns of Legionella species: a molecular identification system. Res Microbiol 1989; 140: 615-626.

8. Koblavi S, Grimont F, Grimont PAD. Clonal diversity of Vibrio cholerae $\mathrm{O} 1$ evidenced by rRNA gene restriction patterns. Res Microbiol 1990; 141: 645-657.

9. Shangkuan Y-H, Tsao C-M, Lin H-C. Comparison of Vibrio cholerae $\mathrm{O} 1$ isolates by polymerase chain reaction fingerprinting and ribotyping. J Med Microbiol 1997; 46: 941-948.

10. Tamayo M, Koblavi S, Grimont F, Castañeda E, Grimont PAD Molecular epidemiology of Vibrio cholerae $\mathrm{O} 1$ isolates from Columbia. J Med Microbiol 1997; 46: 611-616.

11. Damian M, Koblavi S, Carle I et al. Molecular characterization of Vibrio cholerae $\mathrm{O} 1$ strains isolated in Romania. Res Microbiol 1998; 149: 745-755.

12. Koblavi S. Identification et typage moléculaire des Vibrionaceae. PhD thesis. Paris VII University, France, 1996

13. Aidara A, Koblavi S, Boye CS et al. Phenotypic and genotypic characterization of Vibrio cholerae isolates from a recent cholera outbreak in Senegal: comparison with isolates from Guinea-Bissau. Am J Trop Med Hyg 1998; 58: 163-167.

14. Farmer J, Hickman-Brenner F. The genera Vibrio and Photobacterium. In: Balows A, Truper HG, Dworkin M, Harder W, Schleifer KH (eds) The Prokaryotes: a handbook on the biology of bacteria: ecophysiology, isolation, identification, applications, vol 6. New York, Springer-Verlag. 1992: 2952-3011.

15. Tison D. Vibrio. In: Murray PR (ed) Manual of clinical microbiology, $7^{\text {th }}$ edn. Washington DC, ASM Press. 1999: 497-506.

16. Courvalin P, Goldstein F, Philippon A, Sirot J. L'antibiogramme. Paris, MP-VIDEOM. 1985.

17. Grimont F, Grimont PAD. Determination of rRNA gene restriction patterns. In: Howard J, Whitcombe D M (eds) Diagnostic bacteriology protocols. (Methods in Molecular Biology, 46.) Totowa, N J, Humana Press. 1995: 181-200.

18. Fields PI, Popovic T, Wachsmuth K, Olsvik Ø. Use of polymerase chain reaction for detection of toxigenic Vibrio cholerae $\mathrm{O} 1$ strains from Latin American cholera epidemic. J Clin Microbiol 1992; 30: 2118-2121.

19. Trucksis M, Galen JE, Michalski J, Fasano A, Kaper J B. Accessory cholera enterotoxin (Ace), the third toxin of a Vibrio cholerae virulence cassette. Proc Natl Acad Sci USA 1993; 90: 5267-5271.

20. Iredell JR, Manning PA. Biotype-specific tcpA genes in Vibrio cholerae. FEMS Microbiol Lett 1994; 121: 47-54.
21. Regnault B, Grimont F, Grimont PAD. Universal ribotyping method using a chemically labelled oligonucleotide probe mixture. Res Microbiol 1997; 148: 649-659.

22. Grimont F, Chevrier D, Grimont PAD, Lefevre M, Guesdon JL. Acetylaminofluorene-labelled ribosomal RNA for use in molecular epidemiology and taxonomy. Res Microbiol 1989; 140: $447-454$

23. Machado J, Grimont F, Grimont PAD. Computer identification of Escherichia coli rRNA gene restriction patterns. Res Microbiol 1998; 149: 119-135.

24. Varela P, Pollevick GD, Rivas M et al. Direct detection of Vibrio cholerae in stool samples. J Clin Microbiol 1994; 32: 1246-1248.

25. World Health Organization. Cholera in 1993, Part 1. Wkly Epidemiol Rec 1994; 69: 205-212.

26. Nair GB, Shimada T, Kurazono $\mathrm{H}$ et al. Characterization of phenotypic serological and toxigenic traits of Vibrio cholerae O139 Bengal. J Clin Microbiol 1994; 32: 2775-2779.

27. Ramamurthy T, Pal A, Bag PK et al. Detection of cholera toxin gene in stool specimens by polymerase chain reaction: comparison with bead enzyme-linked immunosorbent assay and culture method for laboratory diagnosis of cholera. J Clin Microbiol 1993; 31: 3068-3070.

28. Aidara-Kane A, Boye CSB, Koblavi S, Grimont F, Grimont PAD. Isolation of a new variant of Vibrio cholerae O1: V. cholerae $\mathrm{O} 1$ ribotype $\mathrm{B} 27$ toxinogenotype TB31 during the last cholera epidemic in Senegal. Jpn J Med Sci Biol 1997; 50: 227-232.

29. Shiran I, Nishibuchi M, Ramamurthy T, Bhattacharya SK, Pal SC, Taked Y. Polymerase chain reaction for detection of the cholera enterotoxin operon of Vibrio cholerae. J Clin Microbiol 1991; 29: 2517-2521.

30. Pearson GDN, Woods A, Chiang SL, Mekalanos JJ. CTX genetic element encodes a site-specific recombination system and an intestinal colonization factor. Proc Natl Acad Sci USA 1993; 90: 3750-3754.

31. Faruque SM, Ahmed KLM, Alim ARMA, Qadri F, Siddique AK, Albert MJ. Emergence of a new clone of toxigenic Vibrio cholerae O1 biotype El Tor displacing V. cholerae O139 Bengal in Bangladesh. J Clin Microbiol 1997; 35: 624-630.

32. Kurazono H, Pal A, Bag PK et al. Distribution of genes encoding cholera toxin, zonula occludens toxin, accessory toxin, and El Tor hemolysin in Vibrio cholerae of diverse origins. Microb Pathog 1995; 18: 231-235.

33. Wachsmuth IK, Evins GM, Fields PI et al. The molecular epidemiology of cholera in Latin America. J Infect Dis 1993; 167: $621-626$.

34. Faruque SM, Alim ARMA, Rahman MM, Siddique AK, Sack $\mathrm{RB}$, Albert MJ. Clonal relationships among classical Vibrio cholerae O1 strains isolated between 1961 and 1992 in Bangladesh. J Clin Microbiol 1993; 31: 2513-2516.

35 Faruque SM, Alim ARMA, Roy SK et al. Molecular analysis of rRNA and cholera toxin genes carried by the new epidemic strain of toxigenic Vibrio cholerae O139 synonym Bengal. $J$ Clin Microbiol 1994; 32: 1050-1053.

36. Faruque SM, Roy SK, Alim ARMA, Siddique AK, Albert MJ. Molecular epidemiology of toxigenic Vibrio cholerae in Bangladesh studied by numerical analysis of rRNA gene restriction patterns. J Clin Microbiol 1995; 33: 2833-2838.

37 Desmarchelier PM, Wong FYK, Mallard K. An epidemiological study of Vibrio cholerae $\mathrm{O} 1$ in the Australian environment based on rRNA gene polymorphisms. Epidemiol Infect 1995; 115: 435-446.

38 Popovic T, Bopp C, Olsvik Ø, Wachsmith K. Epidemiologic application of a standardized ribotype scheme for Vibrio cholerae O1. J Clin Microbiol 1993; 31: 2474-2482. 